\title{
The Decline in Legislative Powers and Rise of Authoritarianism
}

Irina Khmelko, University of Tennessee, Chattanooga, USA, guest editor

Political scientists have been working tirelessly for decades, helping people around the world to shed authoritarian governments in favor of more democratic societies. The Third Wave of democratization at the end of the twentieth century brought with it hope and excitement. Political scientists joined forces with policy makers, hoping to find ways to ensure success in democratic transitions and consolidation. Some societies succeeded. Despite initial successes, three decades later, political scientists are deeply troubled by the rise of populism and authoritarianism across the world. What is especially puzzling is that many of these societies have the political will and tools necessary to succeed with democratic reforms. Yet, successful democratization still eludes many societies; indeed, there appears to be a regression of democratic norms and conditions taking place. This group of political scientists from around the world is contributing to this spotlight focusing on the role of legislatures in democracy.

\section{INTRODUCTION: THE DECLINE IN LEGISLATIVE POWERS AND RISE OF AUTHORITARIANISM}

Charles R. Wise, Indiana University

DOI: $10.1017 / S_{1049096518002226}$

This spotlight takes stock of progress following the Third Wave of democratization at the end of the twentieth century. The articles do so by focusing on legislatures as the cornerstone of democracy. Legislatures embody the representative function that provides the crucial link between the public and its government.

Recently, political scientists observed that rising authoritarian and populist trends are threatening the progress of newly formed or reformed democracies around the world. In particular, the concern is that legislatures are ceding power to increasingly assertive executive bodies that work to supplant legislative processes with executive processes, which has marginalized pluralistic voices in developing democratic societies. This undermines the ability of legislatures to fulfill their policy-making function and leads to executive dominance of governments.

The articles in this spotlight reveal various factors that diminish the power of legislatures, including institutional arrangements such as those governing elections that, in several cases, have resulted in single-party dominance (i.e., Russia, Hungary, Poland, India, and Turkey). This dominance has facilitated the ceding of power to executive officials, whether prime ministers, cabinets of ministers, or presidents.

Additional factors include high levels of clientelism and corruption leading to networks of corrupt elites that dominate policy making and undermine legislative activity, as observed in Moldova and Macedonia. Furthermore, in several countries, the authors in this spotlight point to the marginalization of opposition parties and their resultant inability to act as a check on executive excesses. Another factor emphasizes the role of individual legislators. It is pointed out that their capacity has been diminished by inadequate provision of resources dedicated to their legislative activities. This lack of resources renders them unable to formulate or analyze significant legislation. Also, certain legislative rules make it difficult for individual legislators to band together to advance legislative initiatives that they identified as having a common purpose.

Another factor is the economic environment in which the legislature is attempting to formulate policy. Economic crises claimed by the executive have aided them in assuming power under the rationale that only the executive can provide the unified integrated response required to resolve the crisis.

Of course, some developing democracies have fared better than others in confronting the forces weighing against the effectiveness of legislative action. In Ukraine, the combination of governmental system, election laws, and role of the opposition appears to be important in preserving the function of the parliament in undertaking meaningful legislative action. Also, although African legislatures remain weak relative to the executive, most are more powerful and autonomous now than at any time since independence; a small number have become institutions of countervailing power vis-à-vis the executive.

It must be observed that the factors analyzed in these articles do not operate in isolation but rather interact with one another. The authors describe and discuss these interactions. 